\title{
A hőkezelés hatása duplex acél hegesztési varratainak szövetszerkezetére
}

\section{Effect of heat treatment on the microstructure of duplex stainless steel welds}

\author{
Tolnai Ferenc, ${ }^{1}$ Varbai Balázs ${ }^{2}$ \\ Budapesti Műszaki és Gazdaságtudományi Egyetem, Anyagtudomány és Technológia Tanszék, Budapest, \\ Magyarország \\ 1 ferenctolnai1@gmail.com \\ ${ }^{2}$ varbai@eik.bme.hu
}

\begin{abstract}
Duplex stainless steels (DSS) are gaining in popularity due to their characteristic features, excellent mechanical properties, and corrosion resistance. The microstructure of DSSs consists of ferrite up to $50 \%$, and the rest is built up from austenite. The ferritic microstructure can cause chromium-nitride precipitation because the nitrogen solubility in the ferrite phase is very low below $700^{\circ} \mathrm{C}$. Our research showed that electrochemical etching is an acceptable process for revealing chromium-nitrides. Additionally, our research points out that chromium-nitride acts as a secondary austenite nucleation site.
\end{abstract}

Keywords: heat treatment, duplex stainless steels, austenite, electrochemical etching, nitrogen.

\section{Összefoglalás}

A duplex acélok szövetszerkezete általában 50\% ferritből, a fennmaradó rész pedig ausztenitből épül fel. A ferrit fázisban $700{ }^{\circ} \mathrm{C}$ alatt jelentősen csökken az ötvözőként használt nitrogén oldhatósága, ami króm-nitrid-kiválásokat okoz. Kutatásaink során azt találtuk, hogy elektrokémiai maratással kimutathatók a króm-nitrid-kiválások. További eredményként azt kaptuk, hogy a nitridkiválások a szekunder ausztenit nukleációs helyeiként müködnek.

Kulcsszavak: hőkezelés, duplex acél, ausztenit, ferrit, elektrokémiai maratás.

\section{Bevezetés}

A duplex korrózióálló acélok a korrózióálló acélok családján belül nagy szilárdságú alternatívát nyújtanak a tervezőmérnökök számára. A duplex acélok hegesztése azonban rendkívüli figyelmet és a technológiai változók pontos betartását igényli a számos lehetséges nemegyensúlyi átalakulás lehetősége miatt [1, 2]. A megfelelő, 1:1-es ausztenit $(\gamma)$ per ferrit $(\delta)$ fázisarány és ötvözőtartalom megtartása érdekében a duplex acélok hegesztéséhez általában nikkellel túlötvözött hozaganyag vagy nitrogéntartalmú védőgáz ajánlott [3-4].
A duplex acélokat nitrogénnel $(\mathrm{N})$ is ötvözik, mivel a $\mathrm{N}$ ausztenitképző, és jobban oldódik az ausztenitben, mint a ferritben [5]. Ezért, amikor a delta-ferrites szövetszerkezetű acél $1100{ }^{\circ} \mathrm{C}$-ról hül, a delta-ferrit nitrogénben túltelítetté válik, ami króm-nitrid-kiválásokat eredményez $\left(\mathrm{Cr}_{2} \mathrm{~N}\right)$. A kémiai összetétel, a hülési sebesség és a ferritszemcsék mérete olyan tényezők, amelyek meghatározzák, hogy mely kiválások jelennek meg. A nitrogéntartalmú védőgáznak is nagy szerepe van az ausztenit fázis kialakulásának megkönnyítésében, így kevesebb nitrogén ma$\mathrm{rad}$ a ferrit fázisban, és kevesebb $\mathrm{Cr}_{2} \mathrm{~N}$ képződik. 
A szekunder ausztenit $\left(\gamma_{2}\right)$ gyorsan kialakul különböző, hőmérséklettől függő mechanizmusok révén [6]. 600 és $800{ }^{\circ} \mathrm{C}$ közötti hőmérsékleten, ahol a diffúzió gyorsabb, Widmannstätten típusú ausztenitszemcsék alakulnak ki [6]. Bár a $\gamma_{2}$-fázis $\mathrm{N}$-tartalma nagyobb, mint a ferrité, a Cr- és Ni-tartalma lényegében a ferritből képződött ausztenité alatt marad [6]. A 700-900 ${ }^{\circ} \mathrm{C}$ hőmérsékleti tartományban jelenik meg a $\gamma_{2}$ egy másik változata, a $\delta / \gamma$ fázishatáron, amely $\mathrm{Cr}$-tartalmát tekintve szegényebb [6]. Jelen kutatásunkban a króm-nitrid és a szekunder ausztenit fázisok kialakulását vizsgáltuk, hozaganyag nélkül végzett TIG-hegesztés és a hegesztést követő hőkezelés esetén.

\section{Anyagok és kísérleti módszerek}

\subsection{Felhasznált alapanyagok}

A felhasznált alapanyag a volfrámelektródás ívhegesztéshez (TIG-hegesztés) és a hőkezeléshez egyaránt hagyományos, X2CrNiMoN22-5-3 (1.4462) duplex acél volt, $6 \mathrm{~mm}$ vastagságú lemez formájában. A gyártó által megadott kémiai öszszetétel az 1. táblázatban látható.

1. táblázat. Az 1.4462 acél kémiai összetétele a gyártó adatlapja alapján (\%).

\begin{tabular}{|c|c|c|c|c|c|}
\hline $\mathrm{Cr}$ & $\mathrm{Ni}$ & Mn & Mo & $\mathbf{N}$ & C \\
\hline 22,21 & 5,76 & 1,36 & 3,14 & 0,164 & 0,02 \\
\hline Si & $\mathrm{Cu}$ & S & $\mathbf{P}$ & $\mathbf{F e}$ & \\
\hline 0,38 & 0,30 & 0,001 & 0,027 & bal. & \\
\hline
\end{tabular}

\subsection{TIG-hegesztési és hőkezelési kísérletek}

Az egysoros tompakötéseket TIG-hegesztéssel készítettükel 200×50×6 mm-es mintákon, PA (vízszintes) helyzetben, egy egyedi hegesztőautomatával, hozaganyag nélkül. Háromféle ívenergiát alkalmaztunk: $0,25 \mathrm{~kJ} / \mathrm{mm}, 0,84 \mathrm{~kJ} / \mathrm{mm}$ és $1,57 \mathrm{~kJ} / \mathrm{mm}$. Ezek az ívenergiák a duplex acélok ívhegesztéséhez ajánlott 0,5-2,5 kJ/mm tartományba [7] esnek. Az ívenergiát a hőbevitelhez hasonlóan számítottuk, de a termikus hatásfok 1,0 volt. Védőgázként tiszta argont (Ar) vagy 6\% nitrogéntartalmú védőgázkeveréket $\left(\mathrm{Ar}+6 \mathrm{~N}_{2}\right)$ használtunk. A hegesztési folyamat során használt volfrámelektróda $2 \%$ tórium-oxid adalékolású volt, 3,2 mm átmérőben, $40^{\circ}$-os kúpszöggel. A hegesztőautomata az ívhosszt állandó $2 \mathrm{~mm}$-en tartotta minden esetben. A védőgáz áramlási sebessége minden esetben $10 \mathrm{~L} / \mathrm{min}$ volt. A hőkezelést sóolvadékban $(50 \%$ $\mathrm{NaCl}+50 \% \mathrm{KCl}$ ) végeztük $800{ }^{\circ} \mathrm{C}$ hőmérsékleten
10 percig. A hőkezelést csak az argon védőgázzal hegesztett kötéseknél végeztük el. A hőkezelési hőmérséklet és időtartam kiválasztásának oka az volt, hogy megfigyeljük a $\gamma_{2}$ fázis kialakulását a ferrites szövetszerkezetben.

\subsection{Kiértékelési módszerek}

\subsubsection{Metallográfiai vizsgálat}

A metallográfiai vizsgálatra szánt mintákat gyémántkoronggal vágtuk, állandó hűtés mellett, a hegesztett varratból. Vágás után a mintákat 4000-es finomságú csiszolópapíron csiszoltuk, majd $3 \mu$ m-es gyémántszuszpenzióval políroztuk. Az ausztenit és ferrit fázisok kimutatására metallográfiai [8] vagy mágneses [9] vizsgálatok alkalmazhatók. Az ausztenit és ferrit fázisok kimutatására Beraha-2 marószert $\left(85 \mathrm{~mL} \mathrm{H}_{2} \mathrm{O}+15 \mathrm{~mL} \mathrm{HCl}\right.$ + $1 \mathrm{~g} \mathrm{~K}_{2} \mathrm{~S}_{2} \mathrm{O}_{5}$ ) használtunk, amely színes maratásra alkalmas. A maratott csiszolatokról készített felvételeken a ferrit sötéten jelenik meg, az ausztenit pedig világos marad. A lehetséges $\mathrm{Cr}_{2} \mathrm{~N}$-kiválások kimutatása érdekében elektrokémiai maratást végeztünk az MSZ EN ISO 17781:2017 szabvány szerint. A hegesztett mintákat 15\%-os oxálsavban marattuk, $10 \mathrm{~V}$ feszültség mellett, 10 másodpercig, amely maratási eljárás az említett szabvány szerint alkalmas a nitridkiválások kimutatására. Az oxálsavas maratást külföldi kutatók sikeresen alkalmazták korábban a ferritben lévő karbid- és nitridkiválások kimutatására [10,11], ezért mi is ezt az elektrokémiai maratási eljárást alkalmaztuk. A szövetszerkezet vizsgálatát Olympus PMG-3 optikai mikroszkóppal végeztük. A ferrittartalom mérését a maratott mintákról mikroszkóppal készített szövetszerkezeti képeken végeztük el, képelemző szoftverrel, területelválasztáson alapuló módszerrel.

\section{Eredmények és értékelésük}

\subsection{A szövetszerkezet az elektrokémiai maratás után}

$\mathrm{Az}$ 1. ábrán az oxálsavas elektrokémiai maratást követő szövetszerkezeti felvétel látható a $0,25 \mathrm{~kJ} / \mathrm{mm}$ ívenergiával és argon védőgázzal hegesztett minta hőhatásövezetéről. Az ábrát elemezve látható, hogy az oxálsavas elektrokémiai maratás valóban alkalmas a ferritszemcsén belül elhelyezkedő kiválások kimutatására, melyek valószínűsíthetően króm-nitridek.

$\mathrm{Az}$ oxálsavas elektrokémiai maratást követő felvételeken látható szövetszerkezet a külföldi szakirodalomban található eredményekkel 


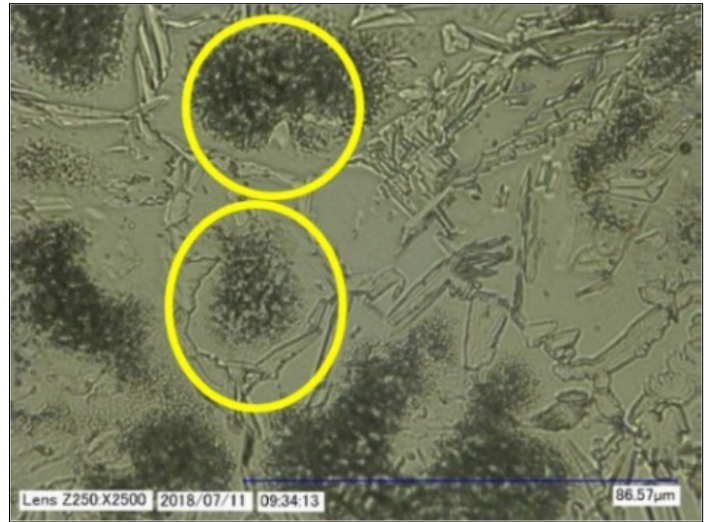

1. ábra. Lehetséges króm-nitrid-kiválások a ferritszemcsék belsejében, a höhatásövezetben. Az ívenergia 0,25 kJ/mm, a védőgáz argon volt

[12-14] hasonló képet mutat. A hivatkozott szakirodalmak ezeket a fázisokat króm-nitridként azonosították, ezért valószínűsíthetően a mi esetünkben is a nitridkiválásokat tette láthatóvá az alkalmazott elektrokémiai maratás. A maratást követő szövetszerkezet-vizsgálat alapján a króm-nitrid-kiválások legnagyobb mennyiségben a legkisebb ívenergiával hegesztett minták esetében keletkeztek, beleértve mindkét alkalmazott védőgázt. Ezek a nitridkiválások a ferrit fázisban, a szemcsék belsejében, valamint nagymértékben a hőhatásövezetben voltak jelen (2. ábra).

Az oxálsavas elektrokémiai maratás viszont oldja a króm-nitrid-kiválásokat, így az összetételük pontos mérésére jelen kutatásunk során nem volt lehetőségünk.

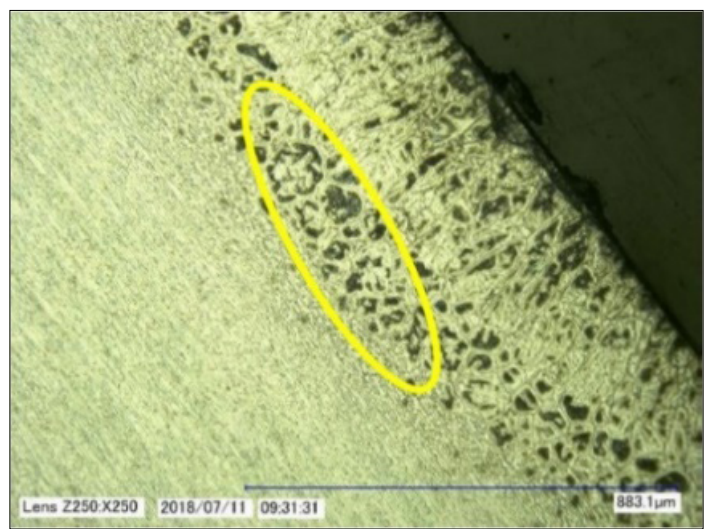

2. ábra. Lehetséges króm-nitrid-kiválások a ferritszemcsék belsejében, a höhatásövezetben. $A z$ ivenergia $0,25 \mathrm{~kJ} / \mathrm{mm}$, a védőgáz argon volt

\subsection{A szövetszerkezet megváltozása a hőke- zelés hatására}

A hőkezelési kísérletet azért végeztük el, hogy a szekunder ausztenit kialakulását elérjük. A 3. ábrából látható, hogy az alkalmazott hőkezelés az ausztenittartalom növekedését eredményezte mind a varratfémben, mind a hőhatásövezetben. Ennek oka a szekunder ausztenit-kiválások megjelenése a ferritszemcsékben az előzőleg megfigyelt nitridkiválások helyén. Látható az is, hogy a szekunder ausztenit kialakulása a ferritszemcsék belsejében indult meg.

Ami az ausztenit arányának változását illeti (4. ábra), megfigyelhető, hogy az ausztenit menynyisége a növekvő ívenergiával csökken a TIG-hegesztett minták esetében, amennyiben védőgázként tiszta argont alkalmaztunk.

A védőgázhoz $6 \%$ nitrogén hozzáadása növelte a varratfém ausztenittartalmát, mivel a nitrogén erős ausztenitképző. Ebben az esetben a varratfém ausztenittartalma $~ 10 \%$-kal haladja meg az alapanyag 50\%-os ausztenittartalmát.

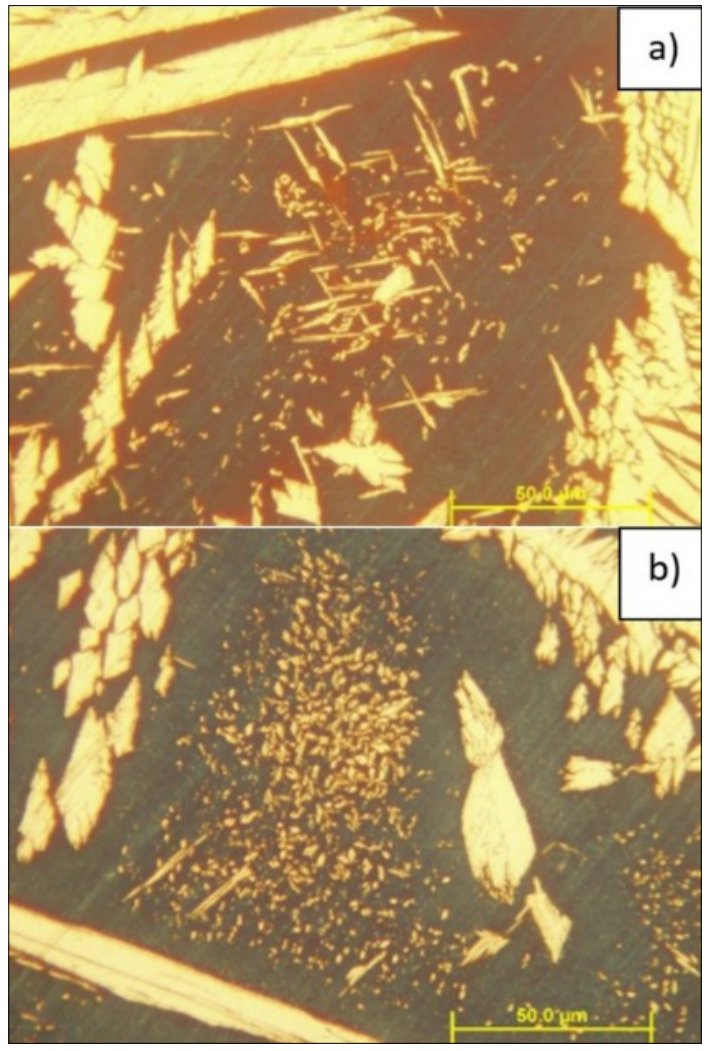

3. ábra. Az argonnal és a legkisebb ivenergiával hegesztett minta szövetszerkezeti felvétele a hökezelés után; (a) varratfém és (b) höhatásövezet 


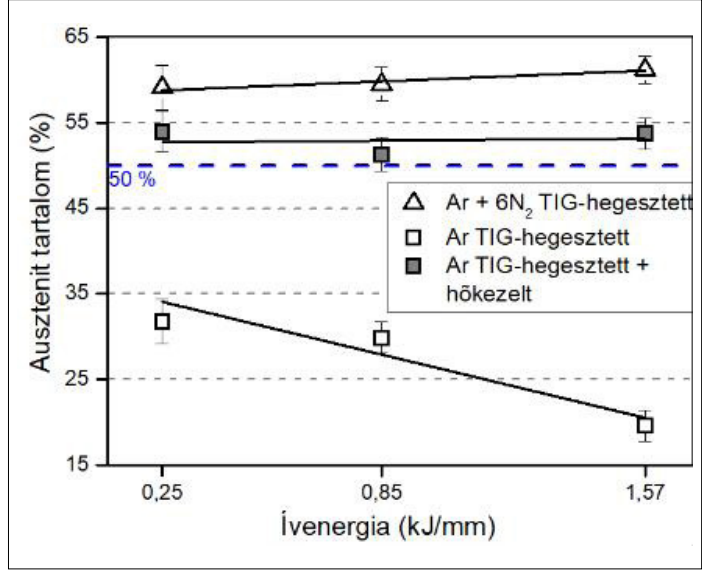

4. ábra. A varratfém ausztenittartalmának változása az ivenergia függvényében, mindkét védőgázzal hegesztett minta és az utólagos hőkezelés esetén

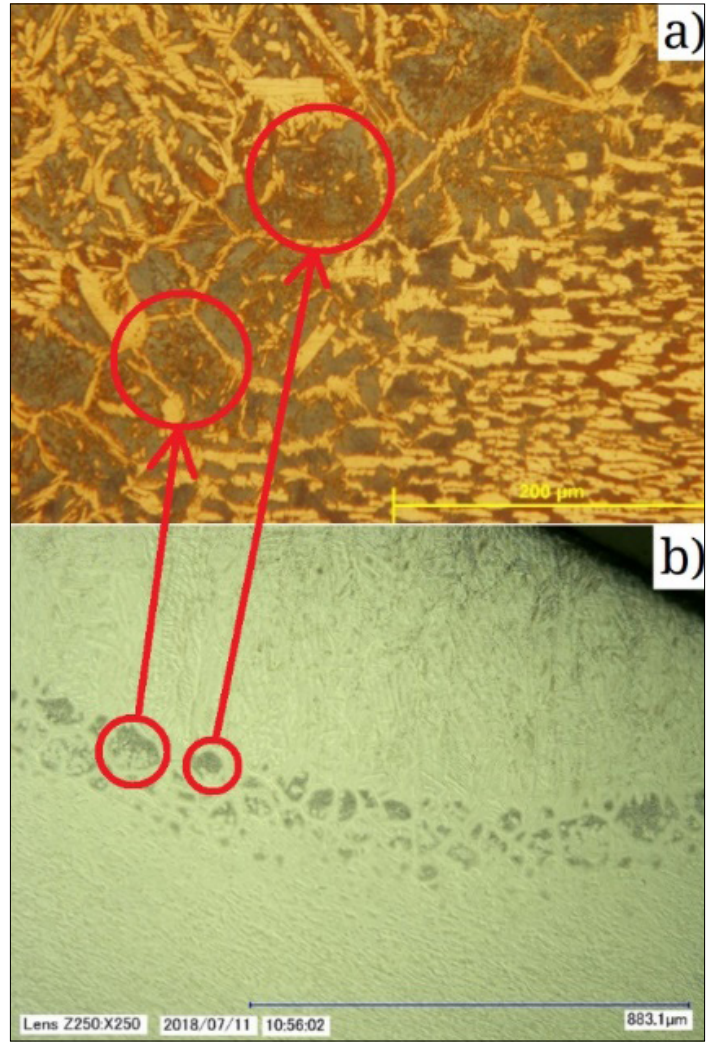

5. ábra. Az argonnal és a legkisebb ívenergiával hegesztett minta hőhatásövezetének szövetszerkezeti felvételei. A szekunder ausztenit és a króm-nitrid-kiválások közötti kapcsolat látható a hőkezelés elötti felvételen (b) és a színes maratással készült felvételen, a hökezelés után (a)
$\mathrm{Az}$ argon védőgázzal hegesztett minta hőkezelése után az ausztenittartalom szintén 50\%-ra növekedett. Az ausztenittartalom növekedése a ferritszemcsékben lezajló $\gamma_{2}$ kialakulásának eredménye, amely fázisban a hőkezelés előtt jelen lévő $\mathrm{Cr}_{2} \mathrm{~N}$-kiválások a másodlagos ausztenit kialakulásának nukleációs helyeként működnek. Mivel a szekunder ausztenit aránya a hőkezelés miatt nagy, arra következtethetünk, hogy a $\gamma_{2}$ nagyon fontos szerepet játszik a valós, többsoros varratkialakítások esetében is, ahol az előzőleg hegesztett varratsorok újrahevülése során jelentősen növelheti a varratfém ausztenittartalmát [9]. Összevetve a színes maratással (5. ábra a) és az elektrokémiai maratással kapott eredményeket (5. ábra b), megállapítható, hogy a króm-nitrid-kiválásoka szekunder ausztenit képződéséhez vezettek a ferritessé vált hőhatásövezetben, amely megfigyelés egyezik más kutatók eredményeivel [14].

A szekunder ausztenit kialakulása a hőhatásövezetben és a varratfémben duplex acélok többsoros hegesztése során is létrejöhet, mely eredményeképpen az ausztenittartalom jelentősen növekedhet [15].

\section{4. Összefoglalás}

Kutatásaink során hagyományos duplex acél TIG-hegesztését végeztük el tiszta argon és nitrogéntartalmú gázkeverék használatával. A tiszta argonnal hegesztett mintákat sófürdős hőkezeléssel utóhőkezeltük. Vizsgáltuk az oxálsavas elektrokémiai maratás alkalmazhatóságát a króm-nitrid-kiválások kimutatására. Ezen felül megvizsgáltuk, hogy ezek a kiválások hogyan alakulnak át másodlagos ausztenitté a hőkezelés során. Eredményeink alapján kijelenthetjük, hogy az oxálsavas elektrokémiai maratás megfelelő módszer a króm-nitrid-kiválások kimutatására. A króm-nitrid-kiválások a hőhatásövezetben voltak láthatók, hőkezelés után pedig másodlagos ausztenitszemcsék képződtek a nitridkiválások helyén, amelyek növelték a varratfém ausztenittartalmát.

\section{Köszönetnyilvánítás}

Jelen cikk az Emberi Erőforrások Minisztériuma NTP-SZKOLL-19-066 kódszámú Nemzeti Tehetség Program pályázatának támogatásával valósult meg.

\section{Szakirodalmi hivatkozások}

[1] Uzonyi S., Asztalos L., Dobránszky J.: Duplex korrózióálló acél durvalemezek hegesztése. Műszaki Tudományos Közlemények, 3. (2015) 315-318. https://doi.org/10.33895/mtk-2015.03.71 
[2] Pálfi N., Berecz T., Fazakas É., Fábián E. R.: Mikroszerkezeti változások $900{ }^{\circ} \mathrm{C}$-on hön tartott, majd alakított SAF 2507 típusú duplex korrózióálló acélban. In OGÉT 2017: XXV. Nemzetközi Gépészeti Konferencia. 25 $5^{\text {th }}$ International Conference on Mechanical Engineering. Kolozsvár, Románia. 2017. 303-306.

[3] Fábián E. R., Dobránszky J., Csizmazia J.: Duplex acéllemezek lézersugaras hegesztésekor bekövetkező változások. Mủszaki tudományos közlemények, 5. (2016) 141-144.

https://doi.org/10.33895/mtk-2016.05

[4] Sándor T.: Korszerü duplex korrózióálló acélok hegeszthetőségi kérdései. In: 25. Jubileumi Hegesztési Konferencia. Budapest, Magyarország. 2010. 19-21.

[5] Westin E. M., Johansson M. M., Pettersson R. F. A.: Effect of nitrogen-containing shielding and backing gas on the pitting corrosion resistance of welded lean duplex stainless steel LDX 2101® (EN 1.4162, UNS S32101). Welding in the World, 57/4. (2013) 467-476.

[6] Gunn R. N.: Duplex stainless steels: microstructure, properties and applications. 1. kiadás. Abington Publishing, Abington, 1997. 30-41.

[7] Karlsson L.: Welding Duplex Stainless Steels - a Review of Current Recommendations. Welding in the World, 56/05/06. (2012) 1-17.

[8] Lőrinc Zs.: NAS329J3L duplex acél lézersugaras felületkezelése. In: Fiatal Műszakiak Tudományos Ülésszaka XIX. Nemzetközi Tudományos Konferencia. Kolozsvár, Románia. 2014. 277-280. https://doi.org/10.36243/fmtu-2014.062
[9] Bögre B., Mészáros I.: Problems of Ferrite Content Determination. Periodica Polytechica Mechanical Engineering, 64/2. (2020) 150-158. https://doi.org/10.3311/PPme.15022

[10] Nelson D. E., Baeslack W. A., Lippold J. C.: Characterization of the weld structure in a duplex stainless steel using color metallography. Metallography, 18/3. (1985) 215-225. https://doi.org/10.1016/0026-0800(85)90043-6

[11] Putz A., Hosseini V. A., Westin E. M., Enzinger N.: Microstructure investigation of duplex stainless steel welds using arc heat treatment technique. Welding in the World, 64. (2020) 1135-1147. https://doi.org/10.1007/s40194-020-00906-2

[12] Pettersson N., Pettersson R. F. A., Wessman S.: Precipitation of Chromium Nitrides in the Super Duplex Stainless Steel 2507. Metallurgical and Materials Transactions A: Physical Metallurgy and Materials Science, 46/3. (2015) 1062-1072. https://doi.org/10.1007/s11661-014-2718-y

[13] Liao J.: Nitride precipitation in weld HAZs of a duplex stainless steel. ISIJ International, 41/5. (2001) 460-467. https://doi.org/10.2355/isijinternational.41.460

[14] Ramirez A. J., Lippold J. C., Brandi S. D.: The relationship between chromium nitride and secondary austenite precipitation in duplex stainless steels. Metallurgical and Materials Transactions A, 34/8. (2003) 1575-1597.

https://doi.org/10.1007/s11661-003-0304-9

[15] Pickle T., Henry N., Morriss P., Tennis L., Wagner D., Baumer R. E.: Root Pass Microstructure in Super Duplex Stainless Steel Multipass Welds. Welding Journal, 98/5. (2019) 123-134.

https://doi.org/10.29391/2019.98.010 